\title{
One Thousand Things Worth Knowing
}

'No better place to start than with the Mescalero girl / who refers to moral // turpitude as moral turpentine' (117), runs an incomplete sentence in 'Dirty Data,' the final alterrative in One Thousand Things Worth Knowing. In their sense-stopping syntax, dispersed line- and stanza arrangement, linguistic confusion and conspicuous italicisation, these verses on the rebellious Amerinidian girl exhibit familiar Muldonic themes and techniques. The title signals a p@stmodernist poem, in which ICT appears as both poetic framework and topic. The ICT component and the confusion between 'moral turpitude' and 'moral turpentine' highlight the scrutiny of knowledge and language the characterises this volume. The balance between them is uneven. Epistemological quandaries tend to outweigh linguistic conundrums as the principal focus of One Thousand Things Worth Knowing. The title signals lucidly this shift in aesthetic orientation. That epistemology challenges the imperative of language in his latest volume from 2015 proposes a distinctive reason for Ben Wilkinson's scathing critique. Judging Muldoon by his own standards, Wilkinson deems One Thousand Things Worth Knowing rock bottom in a continual decline: 'In this often manic hall of mirrors where language and trivia run about, cartoon-like, to a soundtrack of canned laughter and the odd sentimental tune, things seem mainly to go from bad to worse, albeit by the perilously high standards of the Muldoon glory days. Paul Muldoon so rarely gets to any kind of point in this book.' ${ }^{1}$ Yet John McAuliffe finds that 'the weirdness of his linguistic adventure cannot be overstated. ${ }^{2}$ When language assumes a secondary role in Muldoon's poetry, that of the practical function of mediation, the poems lose much of their Shklovskyan estrangement, Adornian radicalism and Derridean discontent. This new parity of esteem in artistic performance between knowledge and language draws attention to another aspect of Muldoon's p@stmodernism: language is no longer the sole predicate. Nevertheless, his linguistic adventures still create an impression of 'weirdness' upon readers, although some critics, Wilkinson in particular, are disgruntled when they judge

1 Ben Wilkinson, 'The Three Ages of Muldoon,' The Poetry Review 105, no. 1 (2015), http://www .benwilkinson.org/2015/07/the-three-ages-of-muldoon-paul-muldoons.html, accessed 5 April 2019.

2 John McAuliffe, 'Paul Muldoon: One Thousand Things Worth Knowing,' The Irish Times, 25 January 2015, http://www.irishtimes.com/culture/books/paul-muldoon-one-thousandthings-worth-knowing-1.2077275, accessed 17 April 2019. 
Muldoon by his own standards. The judgement that Muldoon 'rarely gets to any kind of point in this book,' smacks more of ignorance than knowledge. It's far more likely that Wilkinson is too set on grand ideas, or that he misses many of the points - they are legion, certainly more than one thousand when hermeneutic imagination is activated. Furthermore, Wilkinson's use of 'glory days' as a main criterion of evaluation for new volumes of poetry appears illogical and unreasonable: language, poetry, knowledge and their many relations and contexts change continuously.

Muldoon's twelfth and most recent volume of poetry from Faber and Faber in 2015 - and his publication number thirty-something if you include pamphlets, plays, libretti, criticism, rock lyric volumes, collaborations, selected and collected books - broadens the range and reach of his oeuvre in myriad ways, chiefly in an epistemological direction, while it simultaneously retains a hyperreflective consciousness of language. The title affirms Muldoon's omnivorous appetite for knowledge of all kinds: biology, technology, history, philosophy, mythology, art, literature and language, and, of course, his appetite for arcana, liminality and narthecality, and for 'the esoteric,' 'the pied,' 'the cryptic, the encoded, the runic and the virtually unintelligible,' to mention some domains. ${ }^{3}$ Long lists of poems in Maggot and in his previous poetry develop from detailed knowledge of birds, plants and animals of all kinds, horses in particular. Technological solutions and gadgets known from previous volumes - from electricity in 'The Electric Garden' $(N W, 1-2)$, radio in 'The Radio Horse' $(N W, 21)$ and remote control in 'Yarrow' (AC, 39-189) to the Foley effect in 'The Key' (Mad, 3-4) and information technology in 'Hard Drive' (MSG, 3) and '@' (Mag, 74) reinforce the language, shape, theme, metaphorical and asymmetrical qualities of his poems in this volume too. Histories of Northern/Ireland and the Amerindians and historical events and individuals are richly interwoven. Philosophical dispute and ethical dilemma vie for attention in many verses. Several poems reflect, refract and recreate mythic figures and stories, primarily Irish and classical ones. Incorporation of arts of all kinds, as well as literature from the canon and the works of Muldoon and Heaney and others, forms an intrinsic dimension of the volume. As in his previous Faber collections, Muldoon creates his quoof, italicette, alterratives, narrathanotographies and p@stmodernism. 'The most formally ambitious and technically innovative of modern poets, he writes poems like no one else,' fellow poet and critic Nick Laird avows. ${ }^{4}$ Madoc, this mythic and monstrous alterrative and science fictional nightmare with retinascan and a speaking horse

3 Muldoon, To Ireland, I, 5 .

4 Laird, 'The Triumph of Paul Muldoon'. 
that questions Western metaphysics in a template of American history and multireferentiality, appears as the unappeasable text of Muldoon's languagedriven and knowledge-hunting animus. Maggot, its sibling in titular chime and syllabic similarity, and in specified knowledge and lingual complexity, continues in up-dated modes many of the same techniques. Muldoon excels in knowledge and language. That knowledge and language are important to poetry, is far from new. Samuel Johnson famously points to some of the forefathers in Muldoon's 'polycentric pedigree' in derogatory terms:

The metaphysical poets were men of learning, and, to show their learning was their whole endeavour; but, unluckily resolving to show it in rhyme, instead of writing poetry, they only wrote verses, and, very often, such verses as stood the trial of the finger better than of the ear; for the modulation was so imperfect, that they were only found to be verses by counting the syllables ... The most heterogeneous ideas are yoked by violence together; nature and art are ransacked for illustrations, comparisons, and allusions; their learning instructs, and their subtlety surprises; but the reader commonly thinks his improvement dearly bought, and, though he sometimes admires, is seldom pleased. ${ }^{5}$

Dr. Johnson, like Addison in his condemnation of 'false wit,' denigrates many of the poets by whom Muldoon is inspired. ${ }^{6}$ It is no accident that Muldoon hardly ever, if at all, mentions any poets from the Enlightenment era in all his peregrinations in poetics. He does, on the other hand, praise the metaphysical poets that Dr. Johnson denounces, particularly Donne, for his use of the demotic, and for 'The Flea' - 'one of the poems that makes me think poetry is a truly astonishing art form, and sends me in search of more. ${ }^{7}$ Muldoon indulges in aspects of poetry Dr. Johnson views firmly with disfavour, including the vices or virtues of eclectic knowledge and linguistic multivalence, and he frequently does so to an extraordinary extent. His knowledge intermittently appears more acquired and cognitive than lived and empirical, which is exactly one of the fortes of his poetry. Why is there often such a demand for the understandable,

5 Samuel Johnson, Lives of the Most Eminent English Poets, vol. 1 (London: C. Bathurst et al., $1781), 27$.

6 Addison, 'True and False Wit.'

7 Ligaya Mishan, 'Besieged: A Live Chat with Paul Muldoon,' The New Yorker, 30 October 2009, http://www.newyorker.com/books/book-club/besieged-a-live-chat-with-paul-muldoon, accessed 17 April 2019. See also Dan Eltringham and Kit Toda, 'Paul Muldoon Interview (Part 2), The Literateur (2009), http://literateur.com/paul-muldoon-interview-part-2/, accessed 17 April 2019. 
accessible or palpable in a poem? Why should not one valuable point of poetry be to inspire search for knowledge? Why should not poems inspire further research? Into knowledge of all kinds, as much as into language, literature and arts? John Carey, who berated Muldoon's language in 'The Stain of Words' also upbraided his knowledge in the same article for 'arcane, allusive poetry, packed to the gunwales with higher education.8 Evidently, new words and new knowledge appear as anathema to this professor. Kelsey Osgood, a - much younger? writer and scholar, displays more humility and resourcefulness in pursuit of learning and language. In her earnest, entertaining and encouraging re-review of Maggot she surmounts the threshold of difficulty and allusion that seems to act as a barrier for many reviewers and at least one professor (Carey), to enter the much larger and rewarding room beyond. She also points to all the rooms without threshold:

I'm reminded - somewhat unhappily - of the hours I spent up in my hot attic room in Brooklyn first reading Maggot, then flitting back and forth between Maggot and my enormous, podium-supported OED, and then finally tapping a pencil against my forehead and thinking, " $\mathrm{F} \# \& \&$ it, $\mathrm{f}^{*} \# \&$ it" over and over again in a fatalistic refrain. Still, though, the lighter moments of my dalliance with Muldoon also come to mind. ${ }^{9}$

Osgood explores, through poetic analyses and debate with other reviewers, Muldoon's poetry from a far more productive premise than Carey's:

Complete understanding should not be the goal here ... Rather the ideal ambition is a deepening of one's own knowledge and an opening to the idea that Muldoon's work can serve as a catalyst for acquiring facts and stories irreverent, useless and profound all. ${ }^{10}$

Her conclusion concentrates on a broad-minded responsiveness to some of the epistemological, etymological, ontological and jocoserious strands in the learning and language of Muldoon's poetry:

$8 \quad$ Carey, 'The Stain of Words,' 56.

9 Kelsey Osgood, 'Worth Repeating: Maggot by Paul Muldoon,' Baltimore Review, 18 September 2012, http://baltimorereview.org/index.php/blog/post/worth-repeating-maggot-bypaul-muldoon, accessed 17 April 2019. 
Some mysteries shall remain, such as whether "trampled underfoot" was a direct nod to British rock group Led Zeppelin by the erstwhile librettist and guitar player Muldoon, or if Chazon Ish really was concerned with the etymology of "dork" (doubtful) but one thing is for sure: Maggot [sic] can (but doesn't have to) be the portal into the wider world of Celtic folklore and the history of sideshows. It is an at times gross and difficult challenge such as life, or in Muldoon's words, a "shit storm/ through a bloody stream/ in which every morning the water again runs clear," the clarity of which you ultimately control. ${ }^{11}$

Osgood's intellectual temperament and linguistic openness constitute a proper antidote to cognitive inertia, linguistic indolence and professorial arrogance. In fact, Muldoon's title, One Thousand Things Worth Knowing, could, as Osgood's re-review demonstrates so lucidly, also be read as a riposte to the limited remit of academic analysis of poetry - not only Carey's - in which the classical often outweighs the contemporary, the canonical eclipses the current, and the professorial trumps the popular. Osgood has learnt from both worlds, and others, and is eager to enlarge her knowledge, language, wisdom and life.

Not all reviewers agree with Osgood in general, and certainly not when it comes to One Thousand Things Worth Knowing. 'Muldoon anticipates incomprehension in places,' states Charlotte Runice. ${ }^{12}$ Other reviewers also differ with Osgood about the knowledge and language in the volume. Ann van Buren delineates concisely the knowledge and the uncertainty of the volume: 'Boyish wonder meets a cynical intelligence. Playfulness and seriousness blur to one and the same ... In these poems, we are destined not to know for sure. ${ }^{13}$ Others have reservations, but their interpretative points of view tend to reinforce Muldoon's central position in contemporary poetry. 'If Auden was a guidebook, Muldoon is a scientific journal,' asserts James Marriot and continues, 'indeed, One Thousand Things Worth Knowing often feels like Mercian Hymns on acid. Rather like Hill, Muldoon has developed a late style rich in opaque allusion and incomprehensible reference. ${ }^{14}$ Many reviewers, naturally, draw parallels

$11 \quad$ Ibid.

12 Charlotte Runcie, 'Review of One Thousand Things Worth Knowing,' The Telegraph, 13 January 2015, http://www.telegraph.co.uk/culture/books/bookreviews/11337479/One-Thou sand-Things-Worth-Knowing-by-Paul-Muldoon-review.html, accessed 17 April 2019.

13 Ann Van Buren, 'One Thousand Things Worth Knowing by Paul Muldoon,' The Rumpus (2015), http://therumpus.net/2015/o5/one-thousand-things-worth-knowing-by-paul-mul doon/, accessed 17 April 2019.

14 James Marriott, 'One Thousand Things Worth Knowing by Paul Muldoon,' The Literateur (2015), http://literateur.com/one-thousand-things-worth-knowing-by-paul-muldoon/, accessed 17 April 2019. 
and contrasts with Seamus Heaney, and with Muldoon himself. The reviewer for Publishers Weekly writes: 'All the pointers to earlier work, and to uncommon knowledge, make it less than ideal (except for the Heaney elegy) as an entry point to the Muldooniverse, but it's powerful nonetheless, with witty pleasures and strong feelings to be unlocked and cherished. ${ }^{15}$ More astutely, John Lavin registers that the challenge of Muldoon's poetry is not so much past and present fellow poets as the dramatic development of information technology: 'Paul Muldoon's latest work bombards the senses with information. This is true of all of his collections but the difference on this occasion is that the by-nowfamiliar-blitzkrieg invokes an opposing kind of knowledge saturation: that which is proffered by the Internet.'16

In Muldoon's own epistemological view, as his response below to a question from an audience reveals, knowing cannot be thought without unknowing. The main realm of the unknown is the spiritual dimension - the metaphysical realm beyond empirical facts, instrumental expertise and applied intelligence, the realm and sphere Addison and Dr. Johnson tend to exclude as criteria in their assessment of most eminent poets. Muldoon explains:

Another article of faith (which I touched on briefly) has to do with unknowing, and that, I think, connects it to many experiences that could be described as "spiritual" experiences, and I know you are all familiar with those, where one has a sense of giving oneself over to something beyond oneself, something one doesn't quite understand; and only when one does that, and only in a spirit of humility, is there half a chance that one will come out the other side knowing anything at all in some minor way. So I think I am really pleased that you enter these discussions in the spirit of unknowing, because that is the spirit in which we all engage in the business of trying to write poems. ${ }^{17}$

'It's what you don't know that makes you wiser', one might add. The acquisition of knowledge and the mapping of unknowledge are significant to the act of poetry. Epistemological questioning becomes as important as language philosophy. However, if language was merely referential, the metaphysical

\footnotetext{
15 AA, 'One Thousand Things Worth Knowing,' Publishers Weekly (2014), http://www.publish ersweekly.com/978-0-374-22712-8, accessed 17 April 2019.

16 John Lavin, 'One Thousand Things Worth Knowing by Paul Muldoon,' Wales Arts Review (2015), http://www.walesartsreview.org/poetry-one-thousand-things-worth-knowing-bypaul-muldoon/, accessed 17 April 2019.

17 Laird, 'The Triumph of Paul Muldoon.'
} 
dimension would be the most challenging to render in language. To approach the unknowable requires all dimensions of language. An undefined language that inverts, undermines, questions and speculates upon its own mysteries, flaws and incomprehensibility suits better a grappling with the metaphysical, the spiritual, the unknowable and the unsayable than a language confined by referentiality, logical concatenation, communication and rationality only.

Still, knowable knowledge needs to be correct and verifiable in the first place for a number of reasons. First of all, all Muldoon's catalogues of biological facts, historical events, technological details and erudite knowledge of literature and the arts exist as a distinct acclamatory aspect of his poetry. Knowledge is attractive. It is what we do not know that makes us wiser. Secondly, for a poet to be taken seriously in matters of spirit, soul, ethics and metaphysical dilemma, facts, dates, empiricism and physical phenomena need to be valid and verifiable. Thirdly, Muldoon often makes use of hard science, technology, history and information for imaginative purposes, as poems from The 'Radio Horse' $(N W, 21)$ and 'Madoc' ( $M a d, 13-261)$ to 'The Humors of Hakone' (Mag, 63-72) and '@' (Mag, 74) make clear. Furthermore, Muldoon's poetry often records the philological aspects, imaginative dimensions, hidden cultural equations and the B-sides of the historical record in his tracings of the contours of knowledge. The p@stmodernist '@' epitomises such explorations of knowledge at a contemporary twenty-first century moment when language and knowledge tend to be formatted by information and communication technologies. Transformations in media, communication and language always confine and change contents, message and our understanding of what knowledge is. And language. The transformations of the ICT-revolution of the last decades confirm and constrict as much as they mediate and distribute knowledge, communication and language. One Thousand Things Worth Knowing reacts and relates to the contemporary technological contours of knowledge and communication in the current world in which we live.

In Essay on the Origin of Human Knowledge, Condillac argues against ideality from Plato to Descartes, and for the importance of language to knowledge. Today's information and communication technology creates continuously new languages, novel technological knowledge and increasingly smarter systems of communication. Information and communication technology (ICT), a generic term for the application of computers, telephones, radio, television and similar devices for storing and distributing facts, knowledge and information, marks the revolution of the postmodern world. ICT creates continuously new programming languages, from A+ via Pascal to Zeno, and, apparently, provides boundless space for knowledge. Knowledge can hardly be conceived of without language and the language of ICT and PCs confirms conventional 
structures of writing, speaking and thinking. 'The history of thought is the history of its models,' Frederic Jameson asserts, and explores how structural language, including the 'electronic field' and 'the computer', arrived as a new model that leaped from organising our understanding of the world to a model that, supposedly, illuminates the human condition. ${ }^{18}$ This default of structuralism in any system, such as language, electronic fields, computers and ICT, ultimately confines and closes the possibilities of language. Derrida's idea of grammatology, his philosophical attempt to open up the past to new knowledge and to radically change the future by questioning the structures of language, thought and knowledge, also incorporates admonitions of technological formation in his critique of Western metaphysics:

By alluding to a science of writing reined in by metaphor, metaphysics and theology, this exergue must not only announce that the science of writing - grammatology - shows signs of liberation all over the world, as a result of decisive efforts. These efforts are necessarily discreet, dispersed, almost imperceptible; that is a quality of their meaning and of their milieu within which they produce their operation. I would like to suggest above all that, however fecund and necessary the undertaking might be, and even if, given the most favourable hypothesis, it did overcome all technical [my emphasis] and epistemological obstacles as well as all the theological and metaphysical impediments that have limited it hitherto, such a science of writing runs the risk of never being established as such with that name. ${ }^{19}$

It seems ironic that more or less at the same time as Jameson and Derrida disclose and deconstruct the closure of epistemological systems and language structures, the ICT-revolution solidifies yet again the old paradigms of constrictive cognition and confirmatory language. The whole communication system of ICT would collapse without binary codes and the hardware of information technology manifests in material matter the delimitation of the apparent infinite space of information and knowledge this technology facilitates. ICT facilitates fascinating speed, daily convenience, interactive entertainment and vast resources of facts, knowledge and information, including encyclopedias and dictionaries. Nevertheless, ICT not only confirms old structures and paradigms. Information superhighways also flatten old topographies of language and

18 Fredric Jameson, The Prison-House of Language (Princeton, N.J.: Princeton University Press, 1972), v.

19 Derrida, Of Grammatology, 4. 
knowledge, and leave behind, like wayside shrines, values and wisdom, words, incongruities, irony and idioms, the tertiary and the plural, the aberrant, the different and the deviant. Metaphorically speaking, not least with Muldoon's early and very haunting poem 'Hedgehog' $(N W, 27)$ in mind, the superhighways of information threaten many linguistic beasts and creatures of learning. ICT stimulates and satisfies the search for knowledge. ICT might organise our daily life, like an hour glass organises sand. ICT might offer one thousand and one things worth knowing, but, as Muldoon's poetry in this volume is aware of, it does not illuminate the human condition and it leaves many forms of language and knowledge behind.

Literature comes with the power to break out of Jameson's prison-house of language, and with the endeavour of Derrida's grammatology to open up foreclosed horizons of predominant technical, epistemological, theological and metaphysical paradigms. Writing by Joyce, Mallarmé, Ponge, Robbe-Grillet, Peréc, Shakespeare, Sterne, Valery and other creative authors challenges ordinary constructions of language and cognition in Jameson's critical account of structuralism and Russian Formalism, and in large strata of Derrida's philosophy - not least Acts of Literature. Writing, these 'discreet, dispersed, almost imperceptible' and 'decisive efforts,' sometimes breaks open its own constituent language, and frequently cracks open ideological structures, religious regulations, patterns of thought and the fundamentals of applied science, in its restive powers of anomaly and protean mutability. 'To discover through language some little revision, however slight' and 'to change, to be changed,' Muldoon responds to a question on 'what for you might be the main aim or function of writing?'20 His answer manifest itself in the poematic and theological and metaphysical critique in 'Hedgehog' and the linguistic quandary of 'Quoof.' It finds expression in the 'decisive efforts' of language, and in his philological supplements to the ICT revolution from 'Hard Drive' (MSG, 3) and '@' $($ Mag, 74$)$ to 'Dirty Data' (99-119) in this volume. Muldoon's interventions include. the full gamut of Muldoonisms, alterratives, multirratives and narrathanotographies so abundant in his work. A poetry that incessantly submits to scrutiny the sign, the word, poetry and writing, will also deliver to critique the surrounding discourses, reality and knowledge with which it interacts so imaginatively.

The Enlightenment always appears as the bête-noir and the butt of phallogocentric critique in two of the last millennium's most enlightened thinkers, Foucault and Derrida. One Thousand Things Worth Knowing could to some extent 
be regarded as the poetic phalanx of such paradigmatic critique. The title strikes an uncanny note of appreciation and weariness, almost a sense of lethargy on the part of an avid but intelligent collector. Why, ultimately, is the collection of facts important? What facts? What are the relations of facts to information, knowledge, rationality and wisdom? And thinking? How do organisation of facts and models of knowledge, language and thinking structure individual life, social formations and intellectual activity? Does any of this alleviate the exigencies of the global situation or the quandaries on human existence? Knowledge is of great importance to Muldoon's poetic endeavour, as his insatiable, omnivorous appetite, especially for the recondite and recherché, make evident throughout his entire oeuvre. The recollection of the forgotten, the overlooked and the superceded balances with the engagements with the new. His sense of rationality includes a spiritual dimension, but refrains from any sense of metaphysical redemption. He declares decisively: "The sense of "redress" Seamus Heaney has in mind is associated with a spiritual aspect to poetry and also with some idea that poetry may bring salvation. I go along with him on the first but balk, I fear, at the second. ${ }^{21}$ Muldoon is also acutely aware of the institutions of thought and language with which poetry interacts with circumspection: 'one of the things poetry has been asked to do, and I wonder if it's not unreasonably asked to do, is to stand in for various other institutionalised systems of moral force, most notably of course organised religion. ${ }^{22}$ Muldoon's spiritual aspect, 'where one has a sense of giving oneself over to something beyond oneself, something one doesn't quite understand,' might lie in language itself as his many comments on his faithfulness to language make explicit: 'the only state in which I think anything half-decent might get done is to be humble before the power and possibility of language, to let it have its way with you, as it were. ${ }^{23}$ 'I think one can only be faithful to the language and the way in which it presents itself to you,' 'I am in awe of language.'24 'I am a medium for the poem, it's really not about me. ${ }^{.25}$ Knowledge and unknowing correspond with language, and its power and mystery. These are the larger dimensions of philosophy and spirituality with which One Thousand Things Worth Knowing interacts, but Muldoon would prefer by far not to act up or to play the

\footnotetext{
21 Mishan, 'Besieged: A Live Chat with Paul Muldoon.'

22 Eltringham and Toda, 'Paul Muldoon Interview (Part 2),' http://literateur.com/paul-mul doon-interview-part-2/, accessed 17 April 2019.

23 Keller, 'Interview with Paul Muldoon,' 27.

24 Haffenden, Viewpoints, 133-137.

25 Eltringham and Toda, 'Paul Muldoon Interview (Part 2).'
} 
maggot if the book did not also have a much more specific anchorage than these metanarratives.

One Thousand Things Worth Knowing also takes its title from a very popular tradition, from all trivial pursuit and questions and answers of games and magazines. One possible touchstone for Muldoon's title is the 1000 selected questions from the $Q$ and $A$ page of Pearson's Weekly published by C. Arthur Pearson in 1905: 1000 Curious Things Worth Knowing. An obscure book, 1000 Things Worth Knowing published in 1913 by Nathaniel C. Fowler Jr., suggests another source of associations. As a handbook of facts and information this alphabetically ordered anthology of the accessible and the informative appears as a combination of an encyclopaedia and a self-help book in pocket format. Its author/editor and publisher, Nathaniel C. Fowler Jr., generated a veritable assembly line of such companions, and wrote a quite a few of them himself, including The Art of Story Writing. An apothegm that borders on the realms of epistemological quest, practical information and unintended hilarity meets the reader on the first page of 1000 Things Worth Knowing: 'To find what you want consult the Index.' Veteran readers of Muldoon, and perhaps Muldoon himself, will appreciate the deadpan humour of satisfying desire and assuaging the human predicament by lexical reference, and the humorous absurdity of starting from the end in order to arrive at the right place. The index takes you to sections of edifying and entertaining knowledge. From 'Abbreviations in Common Use' to 'Yankee Doodle,' but nothing really worth knowing under Z, the book sports entries such as 'Errors of History,' 'Failures,' and 'Famous Diamonds;' 'Seasickness' and 'Seven Deadly Sins;' 'Sub Rosa,' 'Sunday Schools' and 'Talking Machines.' It contains lists of 'Presidents of the United States,' 'Principal Countries in the World' and 'Sporting, Speed and Other Records.' 'What to do in Emergencies' takes up 45 pages. Smack full of biblical, classical, economic, mathematical, pathological and philological facts and figures, as well as survival instructions, the book hosts specific facts that are matters of wellestablished historical record. Nevertheless, many of the entries ring with a surprising contemporary topicality: 'Calculating Interest,' 'Coal Industry,' 'Climate and Temperature.' Metaphorical implications for our 21st century condition add further intellectual allure to the 'provocative propinquity' and 'felicitous fusions' of alphabetic orderin of arbitrary facts. ${ }^{26}$ Fowler Jr's Preface states:

This book contains more than one thousand facts, many of which are not generally known to the average person; but all of them are of interest to humankind, and a knowledge of many of them is essential. 
The author has used the simplest English, and has avoided, as far as possible, all technical or scientific terms. He has endeavored not to fall into the common error of making his explanations harder to understand than the subjects treated.

This book is not intended for the scientist, nor does it claim to be exhaustive.

In the space of a few hundred pages the writer has presented the thousand or more things which are really worth knowing, and which are usually described at unprofitable length and without that simplicity of expression so essential to clearness. ${ }^{27}$

This fortuitous meeting of state statistics, general human interest and boy scout handbook between two covers - a personal companion (PC) of its day and a time capsule for our time - bears upon Muldoon's poetry and his own One Thousand Things Worth Knowing in a large number of ways beyond those already indicated in the lines above. Muldoon's very direct allusion to Fowler Jr's mini-encyclopaedia pays ambivalent tribute to the legacies of the enlightenment era, particularly to the intellectual ambitions and industry of encyclopedias. Fowler Jr's book arrives as a manifestation of enlightenment spirit in a popular format, a democratisation of elitist and financially exclusive grand encyclopedias, on the very eve of the destruction wrought by the First World War. Its content and context once again raise many critical questions: what is worth knowing? Why? For whom? According to which criteria? Who decides? What is left out? And does knowledge really help us to tackle the human condition of civic disaster and existential quandary? Critical questions from antipositivist, ethnic, feminist and post-structuralist positions have, especially since the Second World War, beset the enlightenment legacy. Since Jimmy Wales and Larry Sanger's introduction of Wikipedia in 2001 these questions are more relevant than ever. Anthologies of all kinds beg the same critical questions in the realm of literature. ${ }^{28}$ One dimension of Muldoon's oeuvre and his latest volume of poetry reads like a homage to knowledge, irrespective of all concomitant critical questions.

27 Nathaniel C. Fowler Jr., 1000 Things Worth Knowing (New York: Sully and Kleinteich, 1913), Preface, https://archive.org/details/thingsworthknoworfowlgoog, accessed 17 April 2019.

28 'Anthologies, as you know, are minefields. The reviews of every anthology by and large comprise alternate anthologies that the reviewer would produce,' Muldoon responds to Kevin Barry on a question on the reception of his own The Faber Book of Contemporary Irish Poetry (1986). Derek Mahon stated in his review of this anthology that he hoped it would sink without a trace and that Muldoon would live to regret its publication. Kevin Barry, 'Q and A.: Paul Muldoon,' The Irish Literary Supplement (Fall) 1987, 37. 
Muldoon's unstoppable pursuit of knowledge seems to be a life-time venture. Literature, naturally, occupies an important place in his métier - all of his books and essays on literature, his critical reviews and his teaching as well as his poetry demonstrate his expertise in this domain - but other fields appear to hold equal appeal to his autodidactic sensibility: 'I'm pretty interested in general knowledge, and science and arcane knowledge. Much more interested in that than I am in Literature with a capital $L$. Or at least as interested. ${ }^{29}$ This interest of his goes back as least as far as his submersion in language. He reveled in the Junior World Encyclopedia as a child, and praises this fountain of facts as 'a terrific read from aardvark on. ${ }^{30}$ His adult learning has taken on broader dimensions still. The metaphysical and spiritual assume priority, but the physical and scientific are important too: 'I rely on stepping into the unknown, of course. But I'm also relying on some basic laws of physics. And maybe chemistry.' ${ }^{31}$ Muldoon, as all great thinkers, shows humility and respect for the vastness of knowledge: 'Anyway, what I'm saying is: how little one knows.'32 Respect for the unknown and incertitude in crucial questions are aspects of life and thought that Muldoon finds commendable but less common in our day and age: 'This culture, or one's age, does not honour uncertainty. Right? One of the things I like about Obama is that he says, "Well let me think about that..." and, "I'm not sure of the answer to that yet." Which I think is a great thing for anyone to say. ${ }^{33}$ Lack of knowledge proves as important to poetry, his own and others', as knowledge. Unknowability becomes a source of creativity tantamount to humility before language: 'Great poems come from that area: ignorance. ${ }^{34}$ Furthermore, Muldoon is also apprehensively fascinated by how much more he could actually know about eggs, chicken, sausages, avocado and coffee; he comments upon how much he has learned from his cooperation with Warren Zevon; he emphasises the importance of knowledge and ignorance in teaching; and he points to the fact-check of poems in the New Yorker. ${ }^{35}$ Finally, a narrathanotographic self-alertness to the degeneration of cognitive faculties bears upon the endduring zeal for facts, fiction and the unknown:

\footnotetext{
29 Wilson, 'Paul Muldoon, The Art of Poetry,' 72.

$30 \quad$ Ibid., 53.

31 Ibid., 71.

32 Alice Whitwham, 'Interview with Paul Muldoon,' The White Review (July 2013), http:// www.thewhitereview.org/feature/interview-with-paul-muldoon/, accessed 17 April 2019.

33 Ibid.

34 Ibid.

35 Ibid.
} 
I mean, the fact is, whether or not one writes poems, we're all, as we age, getting duller and duller in most instances. One's brain functions less and less effectively. And that's not a matter of opinion, that's a matter of fact. So, whereas there is the engagement with the unconscious, you need to have all your wits about you, and you're losing them all the time. ${ }^{36}$

One Thousand Things Worth Knowing obviously deals with knowledge. Somewhat surprisingly, perhaps, not least in view of the title and the types of knowledge employed for multiple purposes in previous volumes, these poems, like '@' in the previous volume, attend primarily to philological knowledge, and very little to expertise in other fields, such as the plethora of birds and beasts, the historical knowledge and the technological science - not least in 'The Humors of Hakone' - in the preceding Maggot. Knowledge in humanist disciplines informs One Thousand Things Worth Knowing. 'Cuthbert and the Otters,' Muldoon's elegy for Heaney, reveals layers of insight into Heaney's poetics and into the history and myth of the Celtic tradition of Christianity. Ekphrastic poems - 'Charles Émile Jacque: Poultry Among Trees,' 'Barrage Balloons, Buck Alec, Bird Flu, and You,' 'Rita Duffy: Watchtower II,' 'Camille Pissarro: Apple Picking at Eragny-sur-Epte' - take their inspiration, idea and form from paintings. 'Seven Selfies from the Château d'If' gives this tradition of rendering the spirit of the sister art in written form a contemporary Muldoonesque twist. ${ }^{37}$ 'Anonymous: from "Marban and Duaire"' ensues from the long tradition of translating into Anglo-Irish the tenth-Celtic poem about the seventh-century historical figures also known as 'Hermit and King.' 'Pip and Magwitch,' 'A Night on the Tiles with J.C. Mangan,' 'Fredrico García Lorca: “Death,"' 'Álvaro de Campos: "Belfast, 1922,"' 'Cuba (2),' 'Paul Muldoon: "Pompeii”' and 'Seven Selfies from the Château d'If' highlight the inter- and intra-poetic currents that characterise the textual confluence in Muldonic verse, whether such lines of literary learning are highlighted by title, as in these examples, or not, as in so many other verses. 'A Civil War Suit' stages a battle between visual art and verse,

$36 \quad$ Wilson, 'Paul Muldoon, the Art of Poetry', 90.

37 For ekphrastic tendencies in Irish poetry, see Moi, “Drawn by the Coluor and Light": Ekphrases and Aesthetics in the Poetics of Derek Mahon,' 181-197; Johnson, 'The Adoration of the Maggot,' 261-281; Rui Homem, "Private Relations": Selves, Poems, and Paintings Durcan to Morrissey,' in The Oxford Handbook of Modern Irish Poetry, ed. Fran Brearton and Alan Gillis (Oxford: Oxford University Press, 2012), 282-297; Neil Corcoron, 'Modern Irish Poetry and the Visual Arts: Yeats to Heaney,' in The Oxford Handbook of Modern Irish Poetry, 251-266; Elizabeth Bergman Loizeaux, Yeats and the Visual Arts (New York: Syracuse University Press, 2003); Edna Longley, 'No More Poems About Paintings?' in The Living Stream (Newcastle upon Tyne: Bloodaxe Books, 1994), 227-252. 
between ekphrasis and inter-poeticality, between Muldoon and the rest, on the rendition of war in aesthetic form. In this volume, perhaps more substantially than in any other, Muldoon draws attention to 'the spiritual experiences,' 'something beyond oneself, something one doesn't quite understand,' the unknown and all the knowledge that progressively gets lost, like wayside shrines, in today's many transitions in technology, especially information technology, and in the rapid transformations in language and ideological discourses. ${ }^{38}$

The title of Muldoon's latest poetry volume, in its concentration on knowledge and its direct reference to Fowler Jr's companion, implies a reorientation in Muldoon's latest book towards whatever the words, grammar and linguistic phenomena might gesture, and away from introspective and dictionarial reclusiveness. Its focus on humanist knowledge pays homage to ways of thinking and artistic articulation that risk obsolescence and disappearance in the current transitions to the immense possibilities of new models and media of knowledge, for example all the books and scripts that are waylaid in the transition from paper culture to digital infostreams. It is indicative that Wikipedia and Google return very little information on Nathaniel C. Fowler Jr. and his book. This knowledge, as much else in Muldoon's poetry and this volume, stems from sources that tend to be excluded from the present models of 'the history of thought.'39 Muldoon's book, as always, incorporates abundant allusions and vast ranges of reference. However, the adoption of Fowler Jr's book as a likely point of departure suggests in Muldoon's latest volume a change in ambition and circumference away from the poetic agglutination of philosophy, history and literature in such madcap multirratives as Madoc, characterised by speculative forays across the realms of language and semiosis, to a more approachable understanding of knowledge and language. Knowledge could be unknown, abstruse, hidden and arcane, but it also comes in a variety of forms, and can also be known, available, heartfelt and accessible.

Muldoon's poetry not only abounds in knowledge, as his many comments upon the topic articulate so precisely, his poems also brim with the questioning of knowledge. 'Knowing My Place,' his pamphlet from 1971, circles around the placing of the subject in geography, culture, knowledge and language. 'Who's to know what's knowable?' asks the girl in 'Our Lady of Ardboe' $(M, 26)$, an early poem on quotidian life and religious revelation. 'This much I know,' affirms the persona twice in a self-reserved mode in 'Hay' $\left(H, 5^{2}\right)$. 'Go figure' is the command of the last words in the cryptic 'Rune' $(H, 96)$. 'A Collegelands

38 Laird, 'The Triumph of Paul Muldoon.'

39 Jameson, The Prison-House of Language, $\mathrm{v}$. 
Catechism' (MSG, 15-16) dwells upon trivial questions and religious inquiry. 'Riddle' $(H L, 76-78)$ probes into language, communication and various modes of reticence. 'Maybe you'll give me a sign?' asks the final line in 'Love Poem with Pig' (Mag, 73). 'Riddle-me-O / Riddle-me-O,' runs the non-responsive refrain in 'Flags and Emblems' $(H L, 49)$, a poem that questions the personal morals of paramilitary commitment. Watchtower 2 and 'Rita Duffy: Watchtower II,' the jacket image by Muldoon's fellow Belfast artist Rita Duffy and his own ekphrastic poem, cast knowledge in the political and military context of surveillance, secrecy and peril: who collects what type of information on whom for what purposes? It takes little imagination to transpose such crucial dilemmas of human rights and defence of the realm to new technologies of surveillance, and to current conflicts on a national and global scale. The stating, searching and questioning of knowledge reach a high point in One Thousand Things Worth Knowing. And one of the things worth knowing, perhaps the thing, is language.

Language remains a fascinating and intriguing aspect of Muldoon's poetry. Although this volume appears to be Muldoon's least language-driven one to date, he still knows his language and this tendency of knowing marks a difference in his oeuvre: Muldoon tends to acknowledge the resources and possibilities of language more than exploring its mines and pitfalls in One Thousand Things Worth Knowing. Poems in this volume question the line less, offer hardly any wh-sentences, spin fewer one-sentence poetic formations, reduce ergative syntax and employ less arcane vocabulary. No poem examines, exploits or exaggerates the significance of the single letter, the semiosis of a particular sign or the peculiarities of a particular linguistic phenomenon. Very few of the titles, if any, focus attention exclusively on language. Possible exceptions could be: 'We Love the Horse Because Its Haunch' in its curtailed syntax; 'Los Dissidents' for its use of Spanish and perplexing italics; 'To Market, to Market' through its prepositional repetition and, perhaps, 'Required Fields' and 'Dirty Data' in their employment of ICT-terminology and in their reference to the continual revolution that creates, changes and stores our knowledge and language. Nevertheless, Muldoon's ways with language are still of salient importance. One lambent feature is how idioms and colloquialisms almost unnoticeably centre on how we relate to knowledge in our daily speech. 'Notwithstanding the fact,' states the very first line and 'Diseart meaning "a hermitage"' explains another line in the opening elegy for Seamus Heaney, 'Cuthbert and the Otters' $(1,4)$. This factual focus and the furnishing of explanations set the tone for the volume's engagement with empirical knowledge and philology, its forays into spiritual speculation and its concomitant enlightenment scepticism. Slang and science clash in conversation: 'Though you may dismiss as utter tosh / my 
theory' (27). A long string of phrases throughout the verses records surety, ambivalence, uncertainty, dissimulation and a circle of moods and modes of knowledge that are adopted in our common talk: 'there's no denying' (27), 'Am I right in thinking that...' (27), 'I don't suppose' (27), 'I'm pretty sure' $(34,62)$, 'He made me think' (34), 'I doubt'(41), I suppose' $(41,63)$, 'If there's a balance' (64), 'Bear in mind' (69, 70), 'Who would have guessed' (70), 'It seems' (71). Towards the end of the book such remarks assume an increasing ascendancy and degree of conviction, almost as a result of accumulated knowledge from the previous poetic colloquies in the book: 'That's why' $(81,111,116)$, 'I am sure' (89), 'That's right' (99, 103, 105, 108, 110, 113, 116), 'I'm fully aware,' 'I'm well aware,' 'I'm also well aware' (116). 'While knowing in my bones' (80), reverberates with the biblical knowledge of torture and crucifixion in David's messianic psalm 22, and with Muldoon's own foretelling of poetry to come in his debut volume: 'Yet by my broken bones / I tell new weather' $(N W, 3)$. Some of the expressions achieve proverbial status. 'Earth is to all ye know as done is to dusted' (46), sounds like a catachrestic memento mori of knowledge and life with poetic and prosaic echoes. 'The utter / necessity of sin for self-knowledge' (36), gathers in a single sentence the orthodox condemnation of humanism from the Edenic fall to the vilification of Rousseau's Confessions and beyond. There is wisdom too, for poets, readers and critics: 'The best poems, meanwhile, give the answers / to questions only they have raised' (73). Knowledge is diverse in One Thousand Things Worth Knowing, as is the language upon which this diversity of expertise, wisdom and scepticism is predicated.

Sound continues as a particular type of linguistic knowledge and capability in Muldoon's poetry. By talent and training, Muldoon has always cultivated rhymes and chimes, prosody and patterns, as an ineluctable feature of poetic language, and as a stone to trouble the living stream of contemporary poetry. Although Muldoon frequently asserts that most metrics and forms of prosody are specific to language and not unique to poetics, many of his creative solutions stretch the boundaries of ordinary lingual flow and audibility. This time the verses gleam with such chimes as 'Desertmartin - oddly heartened' (4), 'goosedowned truckle - honeysuckle' (14), 'Magwitch - package' (21), 'Portrush partridge' (23), 'jump jet - trumpet' (26), 'utter tosh - out of Bosch' (27), 'little to do - military coup' (64), 'Onassis - nauseous' (75), 'Ben Hourihane - set off a chain,' 'tumble-de-drum - titanium' (100), 'shelter us - glamour-puss' (102), 'load of balderdash - oversee a cache' (107), 'Ford Cortina - Roman quadriga' (110). Language, like knowledge, can also be confusing: "Did I say "calamine"? I I meant "chamomile"' (5). The answer is no; the volume has so far not mentioned anything closer to calamine and chamomile than 'sandstone limen' and 'mustard' (4), if these or other similar auditory, olfactory, gustatory, sensible, 
linguistic or nonsensible connections might be made with what has previously been mentioned. This confusion, nevertheless, is apposite in its signalling of the emotional distress and cognitive dissonance in Muldoon's elegy for Heaney. This multivalent confusion continues in 'Some Pitfalls and How to Avoid Them,' dedicated to Muldoon's son Asher: 'Bear in mind that "calomel" looks a lot like "chamomile" / to the guy trying to compile a camping check list' (69). The alliteration of Cs in these two and many other poems seems as semantically sensible as the confusions of calamine, chamomile and calomel appear logically applicable. They combine in the two poems for Heaney and Asher the 'polycentric pedigree' that runs in Muldoon's poetry from the dedication in New Weather 'for my Fathers and Mothers.'40 The sorrows of Heaney's death, Muldoon's patron, mentor and patrilineal father figure, and the responsibilities of parenthood for his son, belong to the invaluable qualities of life - the relations and responsibilities for which language is not always yet given, and for which there are no easy remedies. Such sounds, such repetitions of sounds, as well as the deployment of just the right word, coalesce in the calibrations of ICT, knowledge and language in 'Recalculating,' a poem in which these strategies serve to open up both knowledge and language.

'Source is to leak as Ireland is to debt' (45). The central sentence in 'Recalculating' has all the power of a proverb. Muldoon's revised sonnet captures with grim irony the recurrent credit crisis that has troubled the Irish economy since the Celtic Tiger. His trick of reversing vehicles in his metaphor and of modulating its timbre yields a confused, almost reversed, situation: Ireland comes second to finance. Debt is no longer a function of the GNP or any particular budget; on the contrary, the GNP and every budget are now functions of Debt. Linguistic catachresis presents the cognitive chiasmus of volatile times. In its use of terminology of source and leak, the central line also hints at the recalibration of political rhetoric in the wake of WikiLeaks. Fourteen similar sounding statements reflect a number of crucial and coincidental issues of our day, some of which are reverted in the second stanza. The linking of lines by starting every new sentence with the final word of the preceding one, infuses an uncanny feeling that somehow these issues connect, like lines in a stanza and stanzas in a sonnet. The title word itself sounds like an admonishing key word to any agile mind, and to backward-looking conservatives and progressive radicals alike. The very appropriate title suggests a view of mathematics and the economy as transitive and in the process change, while it also evokes a computation of technological and digital types, and a renovation of literary metaphors and 
a review of language usage. Such a process of vigilant reconsideration is ongoing, as the present continuous tense makes clear: 'Recalculating.' Furthermore, the title also resonates with current idioms. A G Ps normally says 'recalculating' if the driver misses a turn, before calculating a new possible route, but most drivers know they are better off trusting their own judgement in local terrain. In its recalculating, this poem also turns towards Muldoon's own poetry. In its authoritative sentences, present tense and current concerns, 'Recalculating' tends to respond to the previous likeable lilt, past tense and similar affairs in 'The Old Country' (HL, 38-46). As a reversion of standard figures of speech and thought, these verses bear resemblance to 'Famous First Words' (MSG), they pipe down and broaden the curt corrections of 'Errata' $(H)$ and their catachrestic tendencies hark back to 'Symposium' $(H)$. Appositely, 'Recalculating' associates itself with his other language poems, such as 'Rune' $(H)$ and 'Riddle' $(H L)$, through alliteration. 'Earth is to all you know as done is to dusted,' concludes the final line in a memorable memento mori of mixed idioms. All aims, calculations, knowledge and language will be reset before the ultimate measurement of life. Possibly instigated by a techno-digital device, the GPS, as much as by the credit crunch and associated financial issues, 'Recalculating' draws upon very general knowledge but very specific language details to create a poem that gives words, lines, catachresis and chiasmus to a compendium of the serious, the jocular and the mortal matters of our day and time.

Will the possibilities of technological revolution in communication and information ever be able to comprehend and convey the same anger, anguish, agony, joy and festivity as poetry? Has poetry changed and will it change in the era of ICT? Like a GPS in orientation, online social media, databases, websites, blogs and the profusion of digital devices have undoubtedly altered our ways of coping with disease and death, and with birth and marriage, and the way we celebrate happy occasions. The new social media have already provided entirely new and different platforms, systems and languages for articulating human thoughts and emotions. To some extent the medium is the message; ICT formats its contents. What originally organised our knowledge, ICT, has, as Fredric Jameson argues, become the historical model for the cognition and language of our time. ${ }^{41}$ Google and online dictionaries and encyclopaedias have also facilitated the interpretation of Muldoon's poetry. Undoubtedly, Muldoon is aware of this tendency. A matrix of the almost inescapable daily presence of digital media is at work in the volume. 'Recalculating,' 'Required Fields,' 'At the Lab' and 'Seven Selfies from the Château d'If' connect to the volume's title within this matrix. Many terms and phrases reveal similar combinations: ' 300

41 Jameson, The Prison-House of Language. 
kHz' (5), 'prototype' (6, 87), 'capacity' (22), 'loop' (23, 48), 'scan' (30), 'barcode' (32), 'lab' and 'analyse' (37), 'screen' (56), 'sync' and 'overdub' (65), 'cell' (78), 'battery' (82), 'filed' (86), 'disc' (88) and 'wickiup' (117) are some of the words that connect to the ICT matrix, independently of the context in which they might appear. Loops of letters, repetitions of words, the cut and paste of phrases across poems, high-wire associations and instances of numerological significance are other digits and techniques that reset the ICT matrix in the volume time and again. As always, facts, information, lexicon and language appeal to encyclopaedias and dictionaries, preferably digital ones. 'Dirty Data,' the final poem, appears as a mini-matrix in itself.

Much of Muldoon's knowledge and language in the entire volume as much as in 'Dirty Data,' nevertheless, comes from sources that have not been engulfed by new media. The reference in the volume's title to Pearson's and Fowler Jr's Worth Knowing-books, 'hidden books' of which online searches yield very little, is one example. Muldoon’s p@stmodernist 'Dirty Data' also more than indicates his awareness of the impact of ICT on knowledge, poetry and language. Although substantial amounts of knowledge and language in this poem are searchable, their combination, aporetics and confusions defy the basic structures and amenities of ICT. Muldoon's alterrative here, a surrealist and violent constellation of the incongruous and the surprising, can be read as a Muldoonesque modus operandi, a demonstration of a large number of artistic qualities that illustrate with wit and humour typical human qualities that computers still fall short of: imagination, fantasy, paralogic, aporia, connotations, alterratives and narrathanotographies, the serendipity of mishaps and misreadings, the hermeneutic possibilities of homonyms, the possibility of deconstructing their own binary logic. This does not necessarily imply that the poem is plain sailing for a human mind either, although we have the capacity for processing such contradictory, divergent and perplexing data, particularly after such cornucopias of the complicated and the contrapuntal as 'The More a Man Has the More a Man Wants,' 'Yarrow' and 'Madoc.' 'Dirty Data' offers, among many other creative innovations, the convoluted storylines of the American general, politician and author Lewis 'Lew' Wallace and his famous novel Ben Hur - both the book and the film - as well as the fate of the book's Irish translator, Seosamh Mac Grianna, and copious material from the Northern Irish troubles together with the natural imagery of nesting birds and dancing dolphins. The juxtaposition of the plot in Ben Hur with the American and Northern Irish Civil War, and with the events in the lives of Wallace and Mac Grianna, provides a triangular template for ethical considerations of empire and region, of social order and personal belief, and of a revenge plot turned into stories of forgiveness and redemption. These linguistic phenomena, literary 
techniques and profound human concerns in Muldoon's alterrative appear alien to ICт. They cannot be defined as data, whether dirty or clean.

Dirty data is 'inaccurate, incomplete or erroneous data, especially in a computer system or database,' Wikipedia informs us. ${ }^{42}$ Most aspects of Muldoon's poem do not comply with this definition. Its ethical issues do not belong in a database, its aesthetic dimension defies computer systems, its facts are mainly accurate and its language adheres to non-referential logic. For all its alternatives to ICT, the poem is, nevertheless, as the title confirms so unequivocally, full of dirty data. 'Dirty Data' captures the sense of construed facts, misinformation, collusion and collaboration in the novel Ben Hur and the life of Lew Wallace, in the intelligence and counter-intelligence in civil wars and Northern Ireland and, undoubtedly, in the contemporary wars and the media battles of authorities. WikiLeaks, Snowden, Fox News and Trump are obvious key words. Furthermore, dirty data chimes with dirty wars. Wikipedia explains further on dirty data: 'Unclean data can contain such mistakes as spelling or punctuation errors, incorrect data associated with a field, incomplete or outdated data, or even data that has been duplicated in the database. It can be cleaned through a process known as data cleansing.'43 Most likely, there are no spelling mistakes or punctuation errors in Muldoon's 'Dirty Data.' Many instances appear to be mistaken and erroneous, apart from the fact that they are very unlikely to be mistakes and errors in Muldoon's meticulous and insanely-conceived alterratives. 'Ben Hourihane / falls fuel of the new Roman turbine' (100), for example, which Fran Brearton gives as a typical misphrasing in her review of the book, splices Ben Hur's conflict with Messala to an Irish namesake's incendiary combat against another imperial power. ${ }^{44}$ The deliberate exchange of turbine for tribune also connects with the later 'Mescalero girl who refers to moral // turpitude as moral turpentine' (117). Ignorance, complaisance and carelessness in matters of human rights and social injustice make a combustible cocktail in communities that suffer from lack of moral commitment and parity of esteem. Similarly, 'such is the integrity of their kraal' (101), regarded as a misquotation from Churchill, hints at the English prime minister's involvement in defending the British empire as officer and reporter, particularly his experiences during the Boer War. Other deliberate (mis) phrasings occur too, such as 'Little Miss

42 AA, 'Dirty Data,' in Wikipedia (2017), https://en.wikipedia.org/wiki/Dirty_data, accessed 17 April 2019.

43 Ibid.

44 Fran Brearton, 'Review of One Thousand Things Worth Knowing by Paul Muldoon,' The Guardian, 6 February 2015, https://www.theguardian.com/books/2015/feb/o6/onethousand-things-worth-knowing-paul-muldoon-review-seamus-heaney, accessed 17 April 2019. 
Messala' (102), a humorous effeminisation and diminution of the Roman tribune. 'It looks as if Little Miss Messala, played by a Belfast boy, will clutch / at the idea he might drive a tea-chest bass / to victory' (102), opens up the terrain for more Muldoonisms. Yes, Stephen Boyd from Belfast starred as Messala in William Wyler's film from 1959, that's a fact, and he has ideas of winning the chariot race at Colosseum, both in the film and the book. But 'tea-chest bass?' This jolt is a specimen piece of a surrealist leap. Probably a visualisation of horse and chariot, 'tea-chest bass' also rhymes in Muldoonian fashion with database. The fanciful image of Messala on a tea-chest bass is iconic of how illfitting ICT sometimes appears from the perspective of the humanities. These leaps of language and fantasy could go further. A combination of 'tea chest' and 'Lew' as a search string in Google or You Tube returns a hilarious video on skiffle music by Lew Dite, resplendent with tradition, word play, dead pan humour, narrative abruption, historical baggage and political implications à la Muldoon. ${ }^{45}$ Has Lew Dite done this deliberately or is his video a result of coincidence and circumstance? Facts and information are scant, and the hermeneutic possibilities abound. Is Muldoon aware of Lew Dite's video? Perhaps, perhaps not. Lew Dite's You Tube video certainly plays up a Muldoonian spirit, and illustrates some of the intertextual serendipity that can ensue from Muldoon's search-spurring alterratives. Duplications abound too in Muldoon's poem. 'To add to the confusion' appears many times, as does the inter-authorial bonhomie above facts and rationality: 'That's right, Lew.' However, these examples would only be considered dirty within an ICT rationale. Within language and the arts, Muldoon's poetry in particular, these examples of linguistic play, rhymes and chimes, repetitions and refrains, fanciful phrases and imaginative leaps, offer other means of thinking beyond linguistic referentiality, historical chronology, narrative linearity, mathematical computation, applied logic and binary constructions upon which much of ICT is predicated. The poem ends with a wickiup call:

In your chest safe is the very handkerchief a nonplussed Father Daly waved as a flag of truce on Bloody Sunday. When Pilate lets that hanky fall

it swerves as a morning to those who continue to wine and dine on Massic and edible dormice, not to speak of the Seven Sleepers of Ephesus, for whom this is indeed a wickiup call. (117) 
Bloody Sunday in 1972, the story of Christ (and Ben Hur) and the classical myth of the seven companions in the cave who hibernated for 300 years to escape religious persecution - three significant historical, religious and literary events of the Western world - meet in these final lines. Yet, the final 'wickiup call' seems to be the pivotal point. The call is ambivalent beyond recalculations and dirty data. What could certainly be a Muldoonist crossing of wake up and wiki up is also a synonym for wigwam, wickiup. So, the wake-up call could be issued to ICT enthusiasts and people in general who are unaware of the deficiencies of ICT to comprehend the metaphysical dimension and spiritual matters, and to reflect human trauma and indigenous wisdom, as well as alternative means of understanding and communication. Conversely, the admonition could be posted to all sorts of humanist knowledge and language communities that are still using outdated traditional methods and vocabulary, and still largely uninformed by the dawning possibilities of ICT. The simultaneous entertainment of these two interpretations, and the possibilities of several others, pit imaginative speculation and linguistic multivalence against strictures of binarism and technological instrumentalism. Muldoon's alterrative 'Dirty Data' works, in language and knowledge, as an instance of Derridean grammatology, 'the discreet, dispersed, almost imperceptible signs of liberation,' and as a breach in Jameson's prison house of language and model of contemporary thought. ${ }^{46}$ Poetry would be in danger of disappearing if it were ever submitted to the ICT logic of dirty data, and submitted for cleaning 'through a process known as data cleansing.'47

Mourning might be one of the human emotions in which poetry reveals best its power. Muldoon's poetic language excels in capturing death, mourning and despair in written words, as his many narrathanatographies demonstrate so forcefully. Intense intertextuality and recondite reference, of course, also characterise his artistic idiom. Muldoon mourns Heaney throughout One Thousand Things Worth Knowing. The beginning of 'Dirty Data' alerts the reader yet again to Heaney's presence in the volume. 'The bog is fenced up there on Slieve Guillion, Slieve Guillion where the bracken leaf / still lies behind the Celto-Iberian sword design adopted by the Romans' (99). This first line references Heaney's bog and Viking poems, his attention to natural splendour, his poetic terrain of Northern Irish borderland geography, and his inspiration from Roman historians such as Tacitus and Pliny. Many other poems, for all their interpretational possibilities, relate to Heaney's oeuvre. 'Pelt' exudes some of the rawness of Heaney's initiation into the darker sides of nature in his early

46 Derrida, Of Grammatology, 4; Jameson, The Prison-House of Language.

47 AA, 'Dirty Data,' https://en.wikipedia.org/wiki/Dirty_data. 
poetry and 'Anonymous: From "Marban and Guaire"' shares its spirit with Heaney's chthonic element and consistent gravitation towards Irish mythology. 'Honey' is a veiled anthem to Heaney, who also refers to himself with disarming irony as 'Mr Honey' in his own bee-inspired Virgil-poem 'Glanmore Eclogue' in Electric Light. Furthermore, the two stanzas in Muldoon's sonnet convey both Heaney's portrayal of murder atrocities, most prominent in North, and his more saccharine and bucolic side, perhaps most prominent in Field Work. Translations, ekphrastic poems and a continuous backdrop of conflict and peace in Northern Ireland also connect this volume with Heaney's poetry, as do, of course, the mastery of literary styles and poetic language. Their sodality precedes the publication of Muldoon's first book of poetry. Muldoon changed the title of his 1973 debut volume from The Electric Orchard to New Weather in response to Heaney's Wintering Out of the year before on the advice of Charles Monteith, the Faber and Faber editor to whom Heaney had recommended him. ${ }^{48}$ Heaney reciprocated with Electric Light in 2001. Seamus Heaney's spirit reigns in this volume too, an honorary and natural gesture by Muldoon. Muldoon and Heaney's imaginative interactions and personal relations have inspired both poets from Muldoon's earliest poems, via his funeral eulogy and his bearing of the pall, to his commemoration in One Thousand Things Worth Knowing. ${ }^{49}$ A clause in the first line of 'Dirty Data,' 'the CeltoIberian sword design / adopted by the Romans' (99), refers the reader to 'Cuthbert and the Otters,' Muldoon's elegy for Heaney at the very beginning of the volume, in which the sword holds a central place with the cryptic inscription 'SINIMIAINIAIS' (7).

'The book places the late laureate [Heaney] within history and contemporary culture,' Fiona Sampson writes of One Thousand Things Worth Knowing. ${ }^{50}$ She also points to 'Cuthbert and the Otters' as the preeminent poem in the volume. A large number of reasons support her choice. Muldoon's elegy for Heaney, the treasured poet to whom the Nobel committee awarded the prize in 1995 'for his works of lyrical beauty and ethical depth, which exalt everyday miracles and the living past,' sustains some of the great loss the Nobel laureate's

48 Adam Crothers, 'Paul Muldoon at Faber and Faber', The Literateur (2016), http://literateur .com/paul-muldoon-at-faber-faber-19-september-2016/, accessed 5 April 2019.

49 For more detailed explications of interpoeticality between Muldoon and Heaney, see footnote 7 on page 167 .

$50 \quad$ Fiona Sampson, 'One Thousand Things Worth Knowing by Paul Muldoon,' The Independent, 26 January 2015, http://www.independent.co.uk/arts-entertainment/books/reviews/ one-thousand-things-worth-knowing-by-paul-muldoon-book-review-sombre-lines-ofbeauty-from-a-supreme-10003797.html, accessed 17 April 2019. 
death brought to Ireland and the world, way beyond literary circles. 51 'To me, he [Heaney] was like Lady Gaga or Mick Jagger or Jesus,' Professor of Law Yxta Maya Murray wrote..$^{52} \mathrm{U}_{2}$ front man Bono described Heaney as 'a great, great poet' who 'changed my life. 53 The Irish president Michael D. Higgins paid tribute to a man whose 'contribution to the republics of letters, conscience, and humanity was immense. ${ }^{54}$ Former President of the United States, Bill Clinton, declared: 'Both his stunning work and his life were a gift to the world. His mind, heart, and his uniquely Irish gift for language made him our finest poet of the rhythms of ordinary lives and a powerful voice for peace ... His wonderful work, like that of his fellow Irish Nobel Prize winners Shaw, Yeats, and Beckett, will be a lasting gift for all the world. ${ }^{55}$ Ciaran Carson, companion, poet and for many years the director at the Seamus Heaney Centre at Queen's University, Belfast, averred that 'there is no poet in Ireland who has not been influenced by his example, and is in his debt; but so is everyone who has been touched by his poetry, and they are innumerable.' Fellow writer from Northern Ireland, Patricia Craig, stated that Heaney 'was probably the best-known poet in the world. ${ }^{56}$ Numerous other people from all walks of life paid tribute to Heaney. Some of the impact of Heaney's writing after his death can be studied in, Hearing Heaney, the lecture series at St. Patrick's College at the Dublin City University published in six volumes by Four Courts Press, the two issues of volume eight of Irish Pages entitled 'Heaney' and 'After Heaney,' and special issue 49-50 of The Irish Review. Muldoon contributes to the public commemoration by focusing on Heaney's personality and family life in his heartfelt, humorous and alliterative eulogy at the funeral, 'Seamus Heaney's Beauty. ${ }^{\text {'7 }}$ In his obituary, 'The Mark of a Great Poet,' he writes of Heaney's poetry:

$5^{1} \quad$ Nobelprize.org, 'The Nobel Prize in Literature,' (Stockholm: Nobelprize.org, 1995), https:// www.nobelprize.org/nobel_prizes/literature/laureates/1995/, accessed 17 April 2019. Yxta Maya Murray, 'Punishment and the Costs of Knowledge,' in Hearing Heaney, ed. Eugene McNulty and Ciaran Mac Murchaidh (Dublin: Four Courts Press, 2015), 136.

53 Paul David Hewson, 'President and Taoiseach Lead Tributes to the Late Seamus Heaney,' Independent.ie, 30 August 2013, http://www.independent.ie/entertainment/books/presi dent-and-taoiseach-lead-tributes-to-the-late-seamus-heaney-29539156.html, accessed 17 April 2019.

Ibid.

55 Ibid.

56 Ciaran Carson, 'Tributes to Seamus Heaney,' ввс, http://www.bbc.com/news/uk-north ern-ireland-23899646; Patricia Craig, 'Seamus Heaney Obituary: Nobel Prize-Winning Irish Poet,' The Belfast Telegraph, 31 August 2013, http://www.belfasttelegraph.co.uk/news/ obituaries/obituary-seamus-heaney-nobel-prizewinning-irish-poet-29541684.html, accessed 17 April 2019.

57 Paul Muldoon, 'Seamus Heaney's Beauty,' The New Yorker, 1 September 2013, http://www .newyorker.com/books/page-turner/seamus-heaneys-beauty, accessed 17 April 2019. 
The truth is that he developed into a much more complex poet than anyone might have imagined, one who was increasingly recognized as having insights into not only plows, horses, and frogs, but international politics, human rights, and the attack on the World Trade Center. He was the only poet I can think of who was recognized worldwide as having moral as well as literary authority and, as such, may be the last major poet to even entertain such a possibility. ${ }^{58}$

Heaney's death hit large parts of the world and all of the island of Ireland: 'You must be devastated,' the customs officer said to Muldoon when he arrived in Ireland from the US for the funeral..$^{59}$

It is some of this devastation that Muldoon forges into language, learning and lamentation in 'Cuthbert and the Otters', his elegy for Heaney (13 April 1939 - 30 August 2013). Heaney's exceptional position in life, literature and language provides a primary reason for regarding 'Cuthbert and the Otters' as the preeminent poem in One Thousand Things Worth Knowing, as Fiona Simpson does. ${ }^{60}$ Muldoon also gives priority to this particular poem by placing it first in the volume. A further reason is how Muldoon's elegy distinguishes itself considerably in composition and confusion from all the other condolences and obituaries that have been written, and from his own alliterative and honorary eulogy at the funeral in Dublin on 2 September 2013. The most important reason for the poem's importance is, of course, the quality of the poem and its commemorative powers. For all the superficial and misunderstood criticism of Muldoon's ingenuities of language and his associative shape-changing technique, his elegies have been received with close to universal acclaim, even though many of them reach a pinnacle in the linguistic consciousness and alternative logic for which his poetry has been deplored in some quarters. Muldoon's many narrathanotographies for his undead and deceased father, for Mary Farl Powers, for his mother and sister and Warren Zevon, and this time for Seamus Heaney, have always contributed to the life of his biological and cultural relatives by commemorating them in seering language, form and imagination. These laments also abound with the daring allusiveness and cryptic

$5^{8} \quad$ Paul Muldoon, 'The Mark of a Great Poet,' Daily Beast, 30 August 2013, http://www.thedailybeast.com/articles/2013/o8/30/paul-muldoon-on-seamus-heaney-the-mark-of-a-greatpoet, accessed 5 April 2019 .

59 Helen Vendler, 'Second Thoughts \& Coda,' Irish Pages 8, no. 2 (2014), 19.

6o Sampson, 'One Thousand Things Worth Knowing by Paul Muldoon.' 
knowledge that work in productive tension with the forebodings and grief they also express. Death, loss and mourning all have to do with 'unknowing, the lesser known, the "spiritual" experiences' and the 'something one doesn't quite understand' that Muldoon considers 'another article of faith'- some of the aspects of the human condition that might be better apprehended when entered 'in the spirit of the unknowing.' 'Only in a spirit of humility, is there half a chance that one will come out the other side knowing anything at all in some minor way' ${ }^{61}$ This spirit of unknowing is also immanent in Muldoon's attitude to language; his awe, faithfulness and humility 'before the power and possibility of language,' the paradox that the self or ego must give way to a complete openness and humility before the language. ${ }^{62}$

In his narrathanotography for Heaney, 'Cuthbert and the Otters,' Muldoon approaches, very appropriately, the poetry and legacy of his patron and fellow poet in the same spirit of awe and humility. The title's reference to St. Cuthbert works as a poetic beatification of Heaney, and places him in a spiritual realm of sanctity and longevity. This type of poetic apotheosis also reflects Heaney's reverence for the religious dimension that characterises large parts of his poetry, of which 'Lightenings viii' also known as 'The Monks of Clonmacnoise,' one of the three Heaney poems given on the Nobel website, might be a specimen. The reference in Muldoon's title to the mythical story of the otters paying homage to the saint, recorded in the Venerable Bede's hagiography, points to the aspect of Heaney's poetry that draws upon the wonders of nature, 'The Otter' most of all. 'Mountbatten of Burma. Montgomery of Alamein' (12): Heaney belongs to the premier league of statesmen in times of war. Muldoon's language is in the same league. Vocabulary, phrase and idiom relive Heaney's poetry as much as they extend the vitality of Muldoon's language. 'Shoulder of salmon,' 'little darne,' 'sandstone limen' and 'linden flitch' (3) are some of the words that resound with what Hobsbawn termed 'Heaneyspeak. 'Danes,' 'Bog,' 'berserkers' $(3,4,5$,$) and numerous other phrases are strongly resonant of the$ bog poems and the Viking culture of North in particular. '82nd Airborne,' Lucky Strikes' and 'G.I.' (10) echo Heaney's poems on World War II. 'Like the oracle at Delphi' (5) reverberates with his reverence for classical heritage. 'Orange,' 'Greenwich' and 'red' $(6,7)$ hint at the (political) colour consciousness in much of his verse. 'Refulgent all. From fulgere, "to flash"' (12). The last words in Muldoon's elegy evoke Electric Light and the Nobel Laureate's linguistic radiance

$61 \quad$ Laird, 'The Triumph of Paul Muldoon.'

62 Keller, 'Interview with Paul Muldoon,' 27; Haffenden, Viewpoints, 137; Sherman, 'Interview with Paul Muldoon and Yusef Komunyaka,' 78. 
and wit. Furthermore, the range of languages and dialects in Muldoon's poem, from Irish and Latin to local and demotic idioms, pays homage to Heaney's and his own shared Hiberno-English legacy, their capacity for le mot juste and their life-long interpoetic sodality of imagination. The connection between Muldoon and Heaney's poetry runs like 'the tunnel from Spital Tongues to the staithes' (4).

Muldoon's elegy for Heaney draws on the Nobel Laureate's imaginative realm and incandescent language, but these verses also present some of Muldoon's own linguistic effulgence and encyclopaedic eccentricity. 'Diseart,' 'staithes,' 'frenum,' 'sarabande,' 'smolt' and 'skald' $(4,5,6,9,10)$ are some of the words that might make readers stumble and look for an advanced dictionary. 'SINIMIANIAIS' (7), the inscription on a Viking sword, a mystery equivalent to 'CROATAN' in Madoc, leaves the reader at a loss beyond Google and the Oxford English Dictionary. How do you make sense of and put into words the loss of a close friend and a public figure who is also a prominent poet? The search for words and meanings, and the sense that all responses are inadequate, reflect some of the shock, incomprehension and inarticulacy in the wake of death and bereavement. 'Did I say "calamine?" / I meant "chamomile"' (85). Confusion is rife and remedies do not exist amid the sorrow and grief. Alliterative strings, not least of 'calamine,' 'chamomile,' 'Cuthbert' and Cs, often appear as a secular and maniacal rosary to stave off the thoughts of death and grief: 'Cuthbert whose chalice cloth / will be carried,' 'when it comes to the crunch,' 'an otter cortege / passing under a colonnade' $(8,11)$. Facts are many and many of them appear disconnected: 'The wax moth lives in a beehive proper. It can detect sound frequencies up to $300 \mathrm{kHz}$ (5). Concentration on facts and knowledge also appears as a means to exclude emotional distress. Though not to much avail. 'I am at once full of dread / and in complete denial. / I cannot thole the thought of Seamus Heaney dead' (4). The direct statement flashes like lightening in the third stanza to dissolve all psychological defense mechanisms. Death and dread hit the speaker. This fact is inexorable and incommensurate with all other things. The alliterative monosyllabic rhyme sounds as solid and painful as the clanking of nails into palm or coffin. 'Thole' rings with the power of Beowulf, and of Heaney's translation of the old alliterative epic. ${ }^{63}$ 'I cannot

63 In an empirical quest for the roots and use of the word 'thole,' similar to Stephen's for 'tundish' in A Portrait of the Artist as a Young Man, Heaney writes in his vindication of the Anglo-Saxon epic: 'What I was experiencing as I kept meeting up with thole on its multicultural odyssey was the feeling that Osip Mandelstam once defined as a 'nostalgia for world culture.' And this was a nostalgia I didn't even know I suffered until I experienced its fulfilment in this little epiphany. It was as if, on the analogy of baptism by desire, I had undergone something like an illumination by philology. And even though I did not know 
thole the thought of Seamus Heaney dead' (11). Muldoon's sentence is repeated twice. Its alien ancient word, its simplicity and repetition and sheer desperation, forms a refulgent refrain for the commemoration of Seamus Heaney.

Fittingly, Muldoon makes use of his own type of rhyme royal for his elegy in order to underline Heaney's noble status, and to link Heaney's and his own innovative contributions to form and their canonical status. Muldoon's seven line stanzas of enjambment and freer metre and rhyme add life to the subject matter, Heaney, as they do to the inheritance of Chaucer and Amergin. Muldoon's elegy amounts to 27 stanzas, a number based upon the strength of Celtic culture: 'In the way that 9 and 3 are a perfect match / an Irish war band has 27 members' (4). Furthermore: 'The chiastic structure of the book of Daniel mimics a double ax-head' (11), as does Muldoon's rhyme pattern in the poem. Although many of the stanzas keep their own chimes, the major rhyme scheme observes a chiastic pattern: end words in stanza one rhyme with end words in stanza 27 , stanza two with 26 , etc., until they meet in stanza 14; the stanza that contains the mystic 'SINIMIAINIAIS' sword inscription and its accompanying sentence: 'As for actually learning to grieve, / it seems a nonstarter' (7). The chiastic battle-axe form provides edge, firmness and compositional structure to the welter of contrary emotions in commemorating the life and legacy of Seamus Heaney.

'Cuthbert and the Otters' is placed as the most significant poem in the volume. In subject matter, knowledge and language, Muldoon's narrathanography revivifies Heaney's contribution to the human condition and records his literary powers and moral authority in a manner that takes its inspiration from Heaney. The shriek of desperation at the inadequacies of apt response and the difficulties of finding alinguistic scaffolding that might convey such extremities of emotion is an expression of understandable anger, anguish and agony: ' $I$ cannot thole the thought of Seamus Heaney dead.'

One Thousand Things Worth Knowing brings to the current scene of poetry in 2015 a volume brimful with knowledge, and vibrant with a language that never rests in its own referentiality. Adlinguistic adversity and lingual machinations splice reference to events, to knowledge, to sorrow and joyfulness, with bewildering artifice, literary recursions and fanciful flights to uncertain destinations. The volume belongs to Muldoon's p@stmodernist tendency and its sceptical inquiry into what knowledge is and might be, into how knowledge is distributed and into how some forms of distribution also configure the content that it distributes all align themselves with the wider themes of technocratic

at the time, I had by then reached the point where I was ready to translate Beowulf.

Beowulf (London: Faber and Faber, 1999), xxv-xxvi. 
late modernity; this is the basis for the volume's simultaneous celebration of facts, fiction and language. How the knowable and unknowable relate to each other is a constant theme in a volume that also explores types of language that might articulate the gradations between the two, and the realm of the unknown. To what extent mourning can ever become part of knowledge, comprehension or wisdom, is an open question with which Muldoon grapples with emotional distress, cognitive dissonance and linguistic alacrity in his memorable elegy for Heaney, and in the constant awareness of their shared passion for knowledge, literature and language. The work of both poets attempts to 'overcome all technical and epistemological obstacles,' in Derrida's words. ${ }^{64}$ Muldoon's writings, in all their adlinguistic glides, astounding alterratives and disruptive narrathanographies, also challenge 'the theological and metaphysical impediments' that have so solidly confined the writing and thinking of the Western world. ${ }^{65}$ His writing presents a type that has consistently established itself in the contemporary canon because of its tendency to breach, to quoof, to confound the literary terminology with which his poetry might be defined. More than representing the established, the empirical and the recognisable, Muldoon's poetry endeavours indefatigably to present the forgotten and mislaid, the unknown and unknowable, and the confounded and disconcerting, in a language that constantly runs the risk of rational confusion and communicative collapse. The achievement of Muldoon's poetry is predicated upon incessant inquiry into the inconstant, mutable and capricious phenomena of language, and the dark reality and alienating aspects of existence with which they interact. One Thousand Things Worth Knowing extends that achievement in important ways.

64 Derrida, Of Grammatology, 4.

65 Ibid. 